\title{
Interventional Oncology in Immuno-Oncology Part 1: Thermal Ablation
}

\author{
Ryan Slovak, BS ${ }^{1,2}$ Junaid Raja, MD ${ }^{1}$ Meaghan Dendy Case, MD ${ }^{1}$ Hyun S. Kim, MD ${ }^{1,3,4}$
}

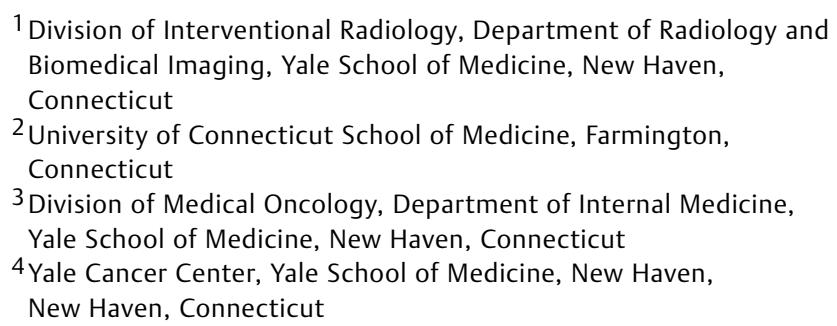

Address for correspondence Hyun S. Kim, MD, Yale School of Medicine, Yale Cancer Center, 330 Cedar Street, TE 2-224, New Haven, CT 06510 (e-mail: kevin.kim@yale.edu).

Dig Dis Interv 2019;3:143-154.

\begin{abstract}
Keywords

- immuno-oncology

- cryoablation

- vaccine

- radio frequency ablation

Thermal ablation occupies a unique position among the various modalities available to treat malignancies. Initially utilized as a minimally invasive form of palliation, ablative techniques are increasingly being recognized for their role in activating an immune response. Locally destructive, but not thoroughly extirpative, thermal ablation function to generate an in situ tumor vaccine capable of stimulating and enhancing both innate and adaptive immune responses. As monotherapy, the response engendered remains therapeutically insufficient, but newer data suggests that when used as an adjuvant or neoadjuvant, ablation may synergistically boost the anticancer immune response produced by other, sequentially acting immunotherapies. The purpose of this review is to discuss the local and systemic immunological effects induced by thermal ablation. Radio frequency, microwave, and cryoablation will all be considered in addition to focused ultrasound ablation.
\end{abstract}

Striking a balance between eradicating a malignancy and minimizing collateral damage has proven to be a persistently elusive goal. As a result, patients undergoing traditional oncologic treatment have often been plagued by side effects and tumor recurrences. Treatments such as external beam radiation or systemic chemotherapy are often not sufficiently tumor specific and the resulting collateral damage may result in significant morbidity. ${ }^{1-4}$ On the other hand, the inability to comprehensively detect and physically remove micrometastases is a limitation of surgical excision that may set the stage for early recurrence. ${ }^{5-8}$

Another option to consider for these patients is interventional oncology. With the use of image-guided percutaneous and catheter-based procedures, interventional oncologists can deliver therapy directly to the tissue in question. Much like surgical excision, many interventional techniques favor precision over systemic efficacy; however, a key difference between these two schools of thought is that interventional oncologists do not remove the cancerous tissue; the tumors are instead destroyed in situ. ${ }^{9}$ Thermal ablation in particular disrupts malignant cells, causing the release of antigens and inducing the expression of proinflammatory cytokines that can go on to activate and prime the immune system to attack occult malignant cells. ${ }^{10}$ While ablation alone may stop short of enacting a complete antitumor immune response, it may help to set the stage for other, more systemically acting immunotherapies by functioning as an in situ tumor vaccine. ${ }^{11-13}$

Though each thermal ablation modality may differ in respect to their exact mechanisms of action, they all induce received

December 17, 2018 accepted

December 23, 2018

published online

March 20, 2019
Issue Theme Ablation Techniques in Liver and Pancreatic Cancers; Guest Editors, Giovanni Mauri, MD, and Miltiadis Krokidis, MD
Copyright $\odot 2019$ by Thieme Medical Publishers, Inc., 333 Seventh Avenue, New York, NY 10001, USA.

Tel: +1(212) 584-4662.
DOI https://doi.org/ 10.1055/s-0039-1679935. ISSN 2472-8721. 
Thermal Ablation RFA, MWA, CA, HIFU
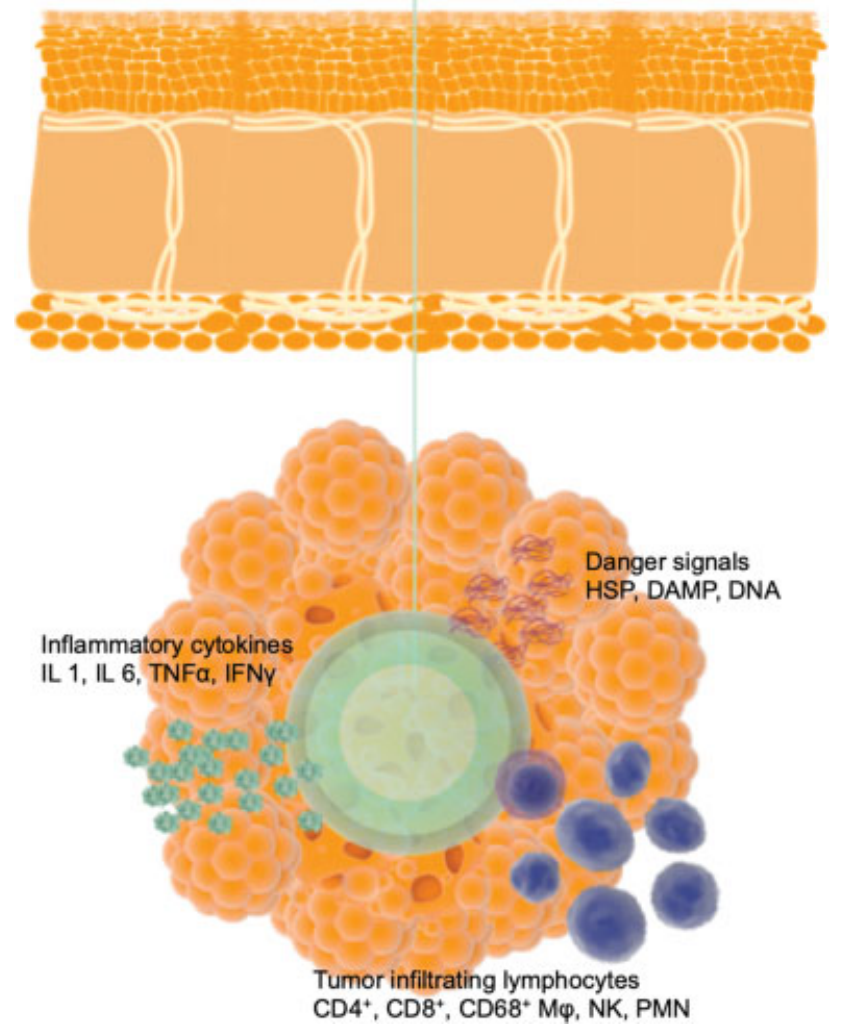

Fig. 1 A general depiction of the cellular disruption and immunostimulation that results from the various forms of thermal ablation. Abbreviations: CA, cryoablation; DAMP, damage-associated molecular protein; DNA, deoxyribonucleic acid; HIFU, high-intensity focused ultrasound; HSP, heat shock protein; IFN- $\gamma$; interferon gamma; IL-6, interleukin 6; MWA, microwave ablation; NK, natural killer; RFA, radio frequency ablation; TNF- $\alpha$, tumor necrosis factor alpha.

necrosis or apoptosis of malignant cells thus exposing antigens that would otherwise escape detection. ${ }^{9,14,15}$ Antigens unveiled by thermal destruction can be taken up by antigen presenting cells that may then go on to prime cytotoxic cells for an antitumor immune response ${ }^{9,16}$ ( - Fig. 1). This ability of ablation to expose the antigenic components of malignant cells to the immune system has been referred to as generating an in situ cancer vaccine. ${ }^{12,16,17}$ Although not the focus of this discussion, it is worth noting that many investigators have sought to capitalize on and enhance this immunogenic effect by combining forms of ablation with medical therapies such as granulocyte-macrophage colony-stimulating factor (Perothech, Rocky Hill, NJ), bacterial-derived immunostimulants, or immune checkpoint inhibitors. ${ }^{18-21}$ The current review will cover the immunological effects that have been observed when thermal ablation is used as a monotherapy.

\section{Radio Frequency Ablation}

Radio frequency ablation (RFA) utilizes applicator probes in conjunction with a grounding pad to generate a high-fre- quency, alternating current. Through frictional heating, this form of ablation is capable of producing temperatures in excess of $60^{\circ} \mathrm{C}$, thereby causing coagulative necrosis of the nearby cells. ${ }^{9}$ When the temperature rises above $100^{\circ} \mathrm{C}$, tissue can char and the impendence to RF current increases drastically, thus limiting the effect of the ablation probe. ${ }^{22}$ Additionally, RFA's mechanism of heating with electromagnetic current is particularly susceptible to the heat-sink effect, where nearby blood vessels siphon away heat and mitigate thermal damage ${ }^{23}$ ( - Fig. 2A).

Thus far, the results of studies seeking to characterize the immune response to RFA have been somewhat variable (-Table 1). For example, Matuszewski et al found in a study of renal cell carcinoma (RCC) that RFA decreased the circulating concentration of $\mathrm{CD} 6^{+} \mathrm{CD}_{16} 6^{+}\left(\mathrm{CD} 56^{\mathrm{dim}}\right)$ natural killer (NK) cells in four out of six patients. Of the remaining two patients in the study, both had an increase in proportion and number of $\mathrm{CD}_{56} 6^{+} \mathrm{CD} 16^{+}\left(\mathrm{CD} 56^{\mathrm{dim}}\right.$ ) NK cells and one maintained a significant increase over the entire 2 months followup period. ${ }^{24}$ In contrast, Zerbini et al reported that RFA of hepatocellular carcinoma (HCC) lesions increases the absolute number of peripheral NK cells along with promoting their activation and functional activity at the 4-week postablation mark. ${ }^{25}$ Notably, Matuszeski's group evaluated a single subtype of NK cells (CD56 $6^{\mathrm{dim}}$ ), whereas Zerbini et al made efforts to distinguish between CD56 ${ }^{\mathrm{dim}}$ and CD56 $6^{\text {bright }}$ populations. In doing so, Zerbini et al identified a significant increase in the $\mathrm{CD} 56^{\mathrm{dim}}$ subset that corresponded to a significant decrease in the CD56 $6^{\text {bright }}$ subset. They further showed that there was no associated significant increase in $\mathrm{K}_{\mathrm{i}}-67$, suggesting that RFA had caused an increase in CD56 ${ }^{\mathrm{dim}}$ cells by inducing a differentiation of NK cells from the CD56 $6^{\text {bright }}$ subset to CD56 ${ }^{\mathrm{dim}}$, thereby shifting NK cells to a more cytotoxic phenotype. ${ }^{25,26}$ Given the variation among Matuszewski's own patients, it is possible that the differing NK cell responses could be due to variables in RFA application or patient biomarker expression that have not yet been fully elucidated.

Similar variations in $\mathrm{T}$ cell response have also been observed after RFA. In the same study as above, Matuszeski's group also identified an increase in the numbers of $\mathrm{CD} 4^{+}$and $\mathrm{CD}^{+} \mathrm{T}$ cells in one out of six patients as well as an increase in the percentage of activated, $\mathrm{DR}^{+} \mathrm{T}$ cells in five out of six patients two weeks after RCC ablation. The numbers of $\mathrm{CD} 4^{+}$ and $\mathrm{CD}^{+} \mathrm{T}$ cells remained significantly elevated throughout the study period, while the proportion of activated T cells declined at week 4 , before rising again at week $8 .{ }^{24}$ Conversely, in a clinical study of RFA for liver cancer, patients with colorectal metastases, but not those with primary disease, demonstrated a transient decrease in $\mathrm{CD}^{+}{ }^{+} \mathrm{CD} 4^{+}-\mathrm{T}$ cells 2 days after ablation. ${ }^{27}$ Likewise, a study by Giardino et al demonstrated that the amount of circulating $\mathrm{CD}^{+}, \mathrm{CD}^{+} \mathrm{T}$, and effector memory $\mathrm{T}$ cells exhibited an initial reduction in numbers that they attributed to surgically induced immune suppression followed by a significant rebound indicative of an activated immune response. ${ }^{28}$ Together these results suggest that the immune response induced by RFA changes over time. 


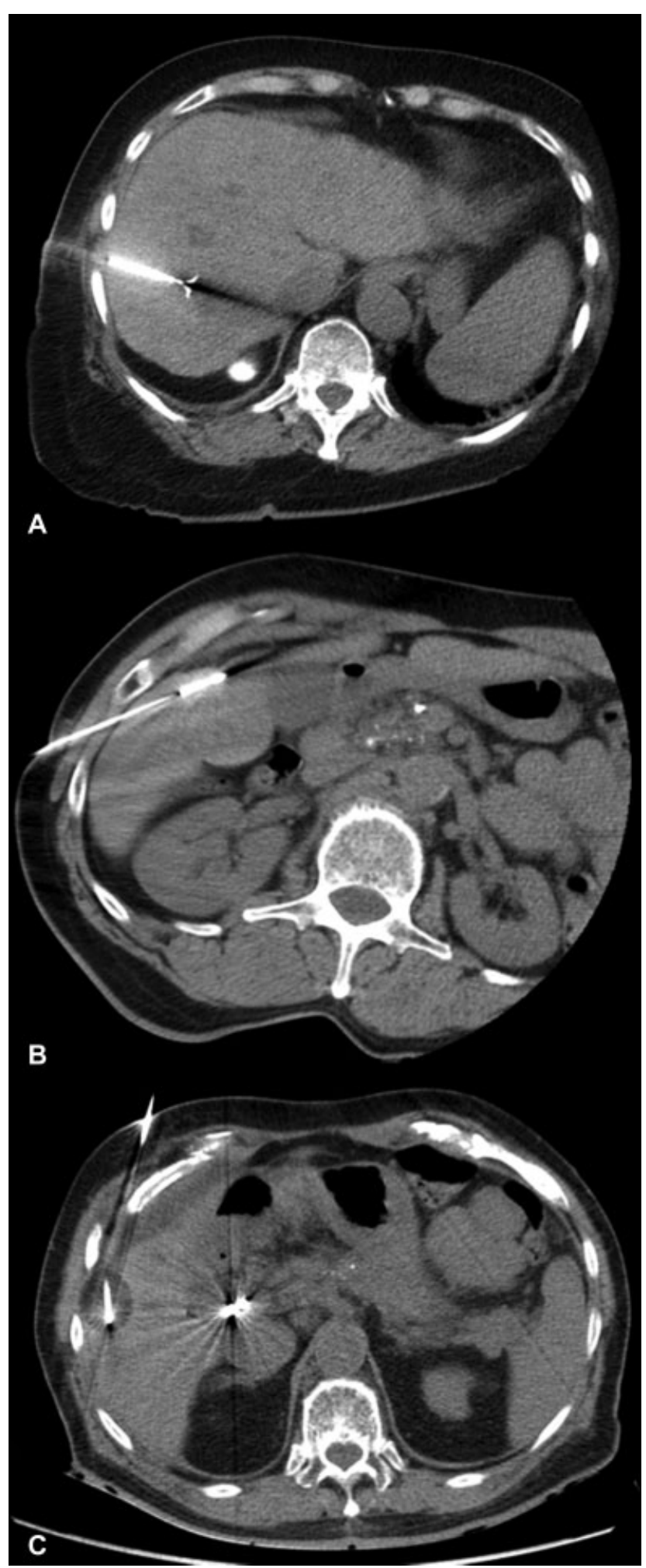

Fig. 2 Computed tomography images obtained during ablation procedures at Yale New Haven Hospital. (A) Radio frequency ablation, (B) microwave ablation, (C) cryoablation.

Significant modulations in other inflammatory markers have also been reported after RFA. In addition to its effects on T cells, Giardino et al also found that RFA was associated with a significant induction of the pro-inflammatory cytokine interleukin 6 (IL-6) and antigen presenting dendritic cells (DC). ${ }^{28}$ Other studies have shown that RFA increases IL-6 as well as IL-1 $\beta$, hepatocyte growth factor, vascular endothelial growth factor (VEGF), and tumor necrosis factor alpha (TNF$\alpha){ }^{29-32}$ However, at least one group has reported that there was no effect on IL-1 $\beta$ or IL- 6 up to 48 hours after RFA treatment of hepatic metastases. ${ }^{33}$ One possible explanation for this outlier is that levels of these inflammatory cytokines vary over time after RFA, just as T cell populations do, but more data are necessary to make that assertion. Numerous studies have also reported on the effect that RFA has on heat shock proteins (HSP), with results showing that RFA significantly induces cellular expression of HSP70 and HSP90, as well as increasing the serum levels of HSP70. ${ }^{34-39}$ Concomitant decreases in nuclear expression of HSP90 suggest that RFA promotes its translocation to the cell surface. ${ }^{34}$

One group that looked specifically at the immune response in intestinal mucosa induced by RFA of the liver in rats found that after ablation, expression of CD4+ T cells, $\mathrm{CD}^{+} \mathrm{T}$ cells, $\mathrm{CD}^{+} 8^{+}$macrophages, and MAdCAM-1 all increased significantly as compared with control. Furthermore, the proinflammatory cytokines TNF- $\alpha$, IL-6, and nuclear factor kappa beta (NF-K $\beta$ ) also increased significantly. ${ }^{40}$ RFA of hepatic tumors has also been shown to induce systemic inflammatory symptoms, elevating temperature, mean arterial pressure, IL-1, adrenaline, and noradrenaline up to 24 hours after the procedure. ${ }^{41}$ Along the same lines, another study showed that RFA produced fever and increased neutrophils only in patients with metastatic liver cancer, not those with primary disease. ${ }^{42}$

Notably, the inflammatory response after RFA has been consistently reported as being less significant than what is seen after cryoablation (CA). ${ }^{30}$ Similarly, while the in situ destruction of tumoral tissue by RFA has been shown to promote DC infiltration, loading, and maturation, it is reportedly far less efficient than in CA. ${ }^{43-45}$

In regard to the effects of RFA on immunosuppression, Giardino et al showed that RFA does not induce expansion or activation of regulatory $\mathrm{T}$ cells. ${ }^{28}$ Other investigators have reported that RFA does not have an impact on the immunosuppressive cytokines transforming growth factor-beta (TGF- $\beta$ ) or IL-10. ${ }^{32,33}$ However, it has also been reported in lung cancer patients that RFA produces a significant reduction in circulating $\mathrm{CD}_{2} 5^{+} \mathrm{FoxP}^{+}$regulatory $\mathrm{T}$ cells that corresponds to increase in CD4+ T cells and interferon gamma (IFN- $\gamma$ ) secreting cells between 30 and 90 days after ablation. ${ }^{46}$ Another group found that while RFA significantly reduced the volume of circulating regulatory $T$ cells $\left(T_{\text {regs }}\right)$, it was less profound than surgical excision. ${ }^{38}$

Several authors have studied the specificity of the antitumor immune response. In a rabbit model of VX2 hepatoma, RFA was able to generate a significant tumor-specific $\mathrm{T}$ cell response as well as dense T cell infiltration. ${ }^{47}$ Clinical studies of primary and secondary liver cancer have shown that RFA is capable of generating tumor-specific antibodies as well as tumor-specific $\mathrm{CD}^{+} / \mathrm{CD}^{+} \mathrm{T}$ cells that may persist for months after treatment. ${ }^{48,49}$ Dromi et al demonstrated the tumor-specific memory response by showing that RFA 
provided protection against tumoral rechallenge. ${ }^{44}$ Another group showed that after RFA treatment, the tumoral antigen mucin 1 (MUC1) was able to stimulate T cells to release IFN- $\gamma$ and increase the amount of circulating B cells. ${ }^{27}$ Mizukoshi et al used an IFN-r enzyme-linked immunospot assay (ELISPOT) assay to analyze the immune response to 11 tumorassociated antigen (TAA) peptides after RFA in HCC patients. They found that an increase in the number of TAA-specific $T$ cells occurred in $62.3 \%$ of patients. Likewise, the increase in tumor-specific $T$ cells was associated with protection from HCC recurrence, although this protection was not sufficient to completely prevent recurrent disease. ${ }^{50}$ Hiroishi et al found similar results, with $80 \%$ of the HCC patients showing a significant increase in TAA-specific CD8+ T cells. They also showed that the magnitude of the specific $T$ cell response was a significant prognosticator for protection against recurrence. ${ }^{51}$ An additional study investigated the ability of RFA to induce a tumor-specific T cell response in patients with HCC. By assessing $\mathrm{T}$ cell reactivity to HCC-derived protein lysates via an IFN- $\gamma$ ELISPOT, as well as via intracellular IFN- $\gamma$ staining, they found that RFA significantly increased antitumor-specific $T$ cell responsiveness, a higher frequency of circulating tumor-specific $\mathrm{T}$ cells, and increased expression of activation and cytotoxic surface markers. However, they also found that this immune response was not sufficient to protect against HCC recurrence. Evidence of eventual immune escape came in the form of a new HCC nodule that was not recognized by the $\mathrm{T}$ cells obtained at the time of ablation. ${ }^{52}$ Other groups have specifically examined the immunological effect that RFA has on distal, untreated lesions. They have found that RFA inhibits distal lesion growth and increases the distal infiltration of neutrophils and $\mathrm{CD}^{+} \mathrm{T}$ cells, but not of $\mathrm{CD}^{+}{ }^{+}$cells. ${ }^{53,54}$

\section{Microwave Ablation}

Microwave ablation (MWA) is a newer form of hyperthermic ablation that differs from RFA in that it utilizes an electromagnetic field to generate heat via dipole agitation and hysteresis, instead of frictional heating via an alternating current. Unlike the current of RFA, the fields generated by MWA are able to pass through tissues with high impedance, and as such it remains effective when tissues char at temperatures above $100^{\circ}$. The size of MWA zones has also been shown to be less affected by local blood vessels (the heatsink effect) than $\mathrm{RFA}^{55}$ (- Fig. 2B).

Compared with the research on RFA, relatively little work has gone into investigating the immunological effects of MWA in isolation (-Table 2). Much of the existing research has examined the effect that MWA has in combination with immunotherapy. In terms of MWA alone, the existing body of evidence seems to suggest that the immune response stimulated by MWA is substantially less than other forms of ablation. One clinical study of MWA for the treatment of HCC found that after ablation, the numbers of T cells, NK cells, and macrophages increased significantly in both the treated and untreated lesions. The same study also found a significant correlation between the level of immune cell infiltration and survival. ${ }^{56}$ Another study that compared forms of ablation found that the levels of IL- $1 \beta$ and IL- 6 induced after ablation were significantly less than after RFA or CA. ${ }^{31}$ Similarly, a different study found that while MWA did induce significant expression of HSP70, the upregulation was less than RFA and CA. ${ }^{57}$

Several studies have compared the immunological effects of MWA alone versus MWA in combination with an immunotherapy. In these papers, valuable data exists on the effect that MWA monotherapy has on the immune system. For example, one study performed on murine model of breast cancer found that after MWA alone there was a significant increase in the tumoral infiltration of $\mathrm{CD}^{+}$and $\mathrm{CD} 8^{+} \mathrm{T}$ cells along with significant increases in their splenic equivalents when compared with control. The same study also identified a statistically significant increase in tumor-specific IFN- $\gamma$ secreting cells as well as an increase in serum levels of IL-12 after treatment. The authors further enhanced these responses with the addition of the immunostimulant, OK432 (Lukang Pharmaceutical, Shandong, China). ${ }^{21}$

\section{Cryoablation}

CA is a unique hypothermic method of ablation; destroying cells by producing local temperatures as low as $-160^{\circ} \mathrm{C}$. These temperatures are achieved via the release of liquid argon gas that rapidly expands and evaporates, thereby extracting the heat out of nearby tissues and generating an ice ball. ${ }^{58,59}$ The alternation of argon and helium gas allows for a rapid freeze-thaw cycle. During the freezing phase, higher intracellular osmolarity initially causes ice crystals to form outside the cell. The resultant change in the osmotic gradient pulls water out of the cell, causing injury via cellular dehydration. When helium is released and the cells thaw, the osmotic gradient reverses, and water rushes back into the cells causing swelling and membrane rupture. As the influx of extracellular fluid lowers intracellular osmolarity, intracellular ice crystals may form, further damaging cellular membranes and organelles. Ice crystals can also form in the walls of nearby blood vessels and cause endothelial damage that initially increases vascular permeability and eventually leads to thrombosis. Occlusion of blood flow causes tissue ischemia that further potentiates tumor cell death $^{9,15,59,60}$ (- Fig. 2C).

There is evidence to show that CA is capable of generating both immunostimulatory and immunosuppressive effects (-Table 3). The prevailing response is believed to be dictated by the ratio of necrotic versus apoptotic cells, with a combination of the two seeming to be ideal. The cells closest to the applicator probe die by necrosis and release "danger signals" in the form of damage associated molecular proteins (DAMPs) such as DNA, RNA, and HSP. ${ }^{61,62}$ Phagocytosis of DAMPs by DC promotes the expression of co-stimulatory molecules necessary for the activation of a cytotoxic $T$ cell response such as CD80 and CD86. ${ }^{63,64}$ On the other hand, physiologic apoptosis is a highly regulated process that does not allow for the release of DAMPs. When DCs process apoptotic cells, the expression of co-stimulatory molecules 
Table 1 A concise description of the significant immunological effects induced by radiofrequency ablation

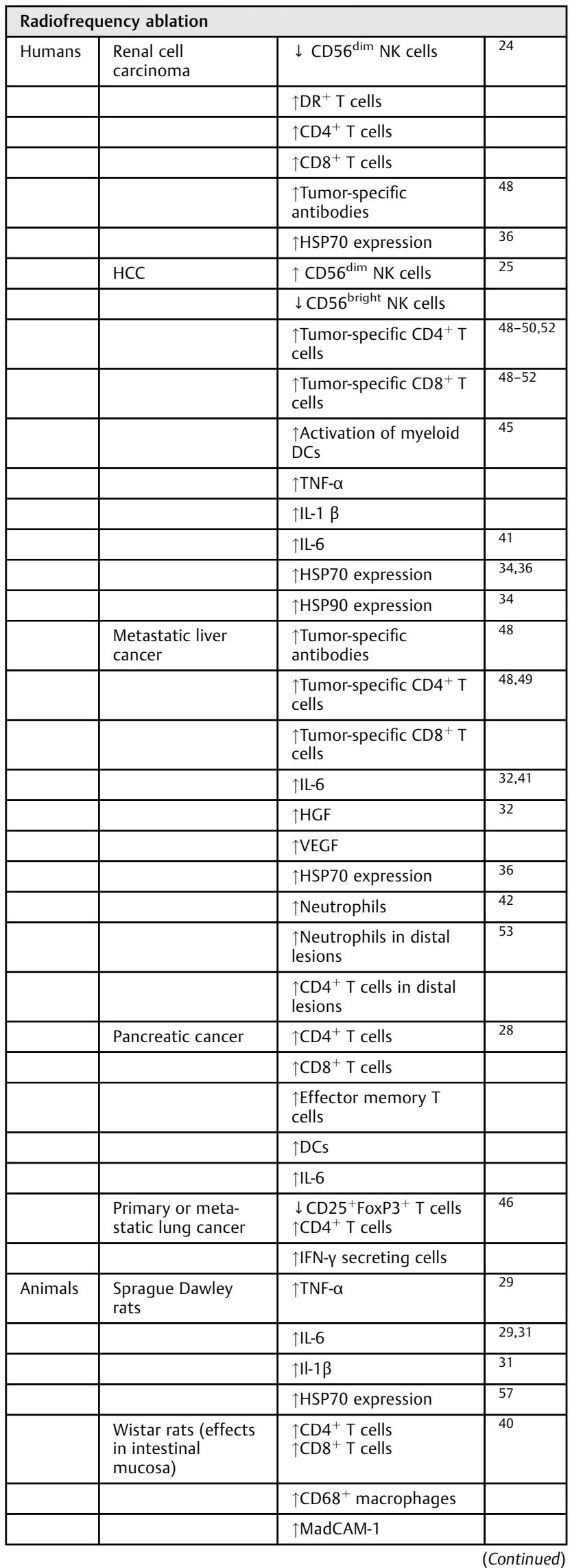

Table 1 (Continued)

\begin{tabular}{|c|c|c|}
\hline \multicolumn{3}{|l|}{ Radiofrequency ablation } \\
\hline & $\uparrow T N F-\alpha$ & \\
\hline & $\uparrow \uparrow I L-6$ & \\
\hline & $\uparrow N F-\kappa \beta$ & \\
\hline $\begin{array}{l}\text { Fisher } 344 \text { rats with } \\
\text { murine breast can- } \\
\text { cer (MatBIII) }\end{array}$ & $\begin{array}{l}\uparrow \text { NK cell infiltration } \\
\uparrow H S P 70 \text { expression }\end{array}$ & 38 \\
\hline & $\downarrow T_{\text {Reg }}$ cells & \\
\hline $\begin{array}{l}\text { Nude rats with } \\
\text { human HCC (SK- } \\
\text { HEP-1) }\end{array}$ & $\begin{array}{l}\uparrow H S P 70 \text { expression } \\
\uparrow H S P 90 \text { expression }\end{array}$ & 35 \\
\hline Domestic swine & $\uparrow \mathrm{TNF}-\alpha$ & 30 \\
\hline & 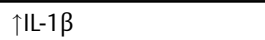 & \\
\hline $\begin{array}{l}\text { C57BL/6N mice } \\
\text { with melanoma } \\
\text { (B16-OVA or B16- } \\
\text { luc) }\end{array}$ & $\begin{array}{l}\uparrow \text { DC loading } \\
\uparrow H S P 70 \text { expression }\end{array}$ & $\begin{array}{l}43 \\
39\end{array}$ \\
\hline $\begin{array}{l}\text { C57BL/6 mice with } \\
\text { urothelial cancer } \\
\text { (MB49) }\end{array}$ & $\begin{array}{l}\uparrow \text { Systemic antitumor } \mathrm{T} \\
\text { cell response }\end{array}$ & 44 \\
\hline & 个Tumor regression & \\
\hline & $\uparrow D C$ infiltration & \\
\hline $\begin{array}{l}\text { BALB/c mice with } \\
\text { murine HCC (BNL) }\end{array}$ & $\begin{array}{l}\uparrow T \text { cell infiltration of } \\
\text { distal lesions } \\
\downarrow \text { Growth of distal } \\
\text { lesions }\end{array}$ & 54 \\
\hline $\begin{array}{l}\text { Nude mice with } \\
\text { human CRC (HT29) }\end{array}$ & $\uparrow \mathrm{HSP70}$ expression & 37 \\
\hline $\begin{array}{l}\text { Rabbit VX } \\
\text { hepatoma }\end{array}$ & $\begin{array}{l}\uparrow \text { Tumor-specific T cell } \\
\text { response }\end{array}$ & 47 \\
\hline & $\uparrow \mathrm{T}$ cell infiltration & \\
\hline
\end{tabular}

Abbreviations: CRC, colorectal cancer; DC, dendritic cell; HCC, hepatocellular carcinoma; HGF, hepatocyte growth factor; HSP70, heat shock protein 70; IFN-ץ, interferon gamma; IL-6, interleukin 6; NF-K $\beta$, nuclear factor kappa beta; NK, natural killer; SK-HEP-1,-; TNF- $\alpha$, tumor necrosis factor alpha; VEGF, vascular endothelial growth factor.

is inhibited and the immune system is suppressed. ${ }^{65-67}$ If the volume of apoptotic cells exceeds the body's ability to clear it, the cells may become secondarily necrotic. Danger signals released from secondarily necrotic cells or nearby necrotic cells might be sufficient to trigger the maturation of DCs that have taken up apoptotic remnants. ${ }^{68}$ In fact, CA has been shown to rescue the function of tumor-induced tolerogenic DC, downregulating their expression of IL-10 and allowing them to again act in an immunostimulatory manner. ${ }^{69}$ Newer studies suggest that apoptotic cells themselves may be capable of releasing DAMPs and stimulating DC maturation in a process referred to as immunogenic cell death. 66,67

As an example of how the ratio of necrotic to apoptotic cells can shift the immunologic response to $\mathrm{CA}$, the rate of freeze has an effect on the extent of necrosis as well as the magnitude of the immunostimulatory response induced by CA. Faster rates are associated with a significant increase in tumor-specific $\mathrm{T}$ cells in draining lymph nodes as well as decreased pulmonary metastases and prolonged survival when compared with slower rates. Interestingly, a low rate 
Table 2 A concise description of the significant immunological effects induced by microwave ablation

\begin{tabular}{|c|c|c|c|}
\hline \multicolumn{4}{|c|}{ Microwave ablation } \\
\hline \multirow[t]{6}{*}{ Humans } & $\begin{array}{l}\text { Hepatocellular } \\
\text { carcinoma }\end{array}$ & $\uparrow T$ cell infiltration & 56 \\
\hline & & $\begin{array}{l}\uparrow N K \text { cells } \\
\text { infiltration }\end{array}$ & \\
\hline & & $\begin{array}{l}\uparrow \text { Macrophage } \\
\text { infiltration }\end{array}$ & \\
\hline & & $\begin{array}{l}\uparrow T \text { cells in distal } \\
\text { lesions }\end{array}$ & \\
\hline & & $\begin{array}{l}\uparrow \text { Macrophages in } \\
\text { distal lesions }\end{array}$ & \\
\hline & & $\begin{array}{l}\uparrow N K \text { cells in distal } \\
\text { lesions }\end{array}$ & \\
\hline \multirow[t]{6}{*}{ Animals } & $\begin{array}{l}\text { Sprague Dawley } \\
\text { rats }\end{array}$ & $\uparrow \mathrm{HSP70}$ expression & 57 \\
\hline & $\begin{array}{l}\text { BALB/c mice } w / \\
\text { murine breast } \\
\text { cancer ( } 4 \mathrm{~T} 1)\end{array}$ & $\begin{array}{l}\uparrow \mathrm{CD} 4^{+} T \text { cells } \\
\text { infiltration } \\
\uparrow \mathrm{CD} 8^{+} T \text { cells } \\
\text { infiltration }\end{array}$ & 21 \\
\hline & & $\begin{array}{l}\uparrow \text { Splenic CD4 } \\
\text { T cells }\end{array}$ & \\
\hline & & $\begin{array}{l}\uparrow \text { Splenic CD8 }{ }^{+} \\
\text {T cells }\end{array}$ & \\
\hline & & $\begin{array}{l}\uparrow \text { Tumor-specific } \\
\text { IFN-y secreting cells }\end{array}$ & \\
\hline & & $\uparrow I L-12$ & \\
\hline
\end{tabular}

Abbreviations: HSP70, heat shock protein 70; IFN-y, interferon gamma; IL-12, interleukin 12; NK, natural killer.

of freezing was actually associated with an increase in $\mathrm{T}_{\text {reg }}$ cells and a resulting suppression of $\mathrm{CD}^{+} \mathrm{T}$ cell stimulation. ${ }^{70}$

There is some data to suggest that the immune response to CA changes over time from immunosuppression to immunostimulation. In a series of papers published between 1982 and 1998, one group observed an initial increase in immunosuppression that they suggested could be due to the induction of splenic suppressor $\mathrm{T}$ cells (now known as $\mathrm{T}_{\text {reg }}$ cells). ${ }^{71-74}$ Another group identified an increase in the population of splenic suppressor $T$ cells $\left(T_{\text {regs }}\right)$ after $C A$ only between 1 and 10 days after treatment. ${ }^{75}$ Using a rat model of breast adenocarcinoma, Misao et al found that while mice treated with surgical excision had a superior response to re-challenge 1 to 3 weeks after treatment, the mice that had been cryoablated experienced a significantly higher rejection rate than surgery at week 10 . At this time point, only $18 \%$ of the surgically treated rats rejected the rechallenge, compared with $80 \%$ in cryoablated mice. ${ }^{76}$ An additional study concluded that after CA there is early immunosuppression followed by increasing tumor draining lymph node cellularity and resistance to rechallenge that peaks at ten weeks. ${ }^{77}$ It is possible that early after CA, the immunosuppressive signals from the apoptotic cells are dominant, but as the body fails to clear those cells and they become secondarily necrotic, the response shifts to an immunostimulatory one.

There is a robust body of evidence to support the immunostimulatory response induced by CA. Samples of tumor tissue taken after ablation in kidney cancer patients have demonstrated elevated transcriptional levels of $\mathrm{CD} 8^{+}, \mathrm{CD} 4^{+}$, $\mathrm{CD} 11 \mathrm{c}$, and granzyme $\mathrm{A}$ along with a high $\mathrm{CD}^{+} / \mathrm{FoxP}^{+}$ ratio. ${ }^{78}$ In melanoma patients, $C A$ has been associated with a significant increase in the number of circulating total and helper T cells, as well as in HLA-DR ${ }^{+}$antigen presenting cells, and in the ratio of helper to suppressor T cells. ${ }^{79}$ Several animal studies have also highlighted a postablative increase in tumor-specific cytotoxicity as well as a significant increase in infiltrating neutrophils, macrophages, $\mathrm{CD} 4^{+}$, and $\mathrm{CD}^{+} \mathrm{T}$ cells after CA, particularly at the periphery of the ablation zone, where the hypothermic injury is sublethal and apoptotic cell death occurs. ${ }^{80,81}$ A murine model was also used to demonstrate that there is an increase in the ratio of IFN- $\gamma$ to IL-4 after CA, suggesting that there is a postablative shift in the ratio of Th1 to Th2 effector cells. ${ }^{80}$ In a trial conducted on patients with primary and metastatic liver cancer, a post-CA increase in the ratio of IFN- $\gamma$ to IL- 4 as well as an increase in TNF- $\alpha$ and a decrease in IL-10 were all associated with tumor necrosis outside of the treatment area. ${ }^{82}$ Another study that sought to investigate the prognostic ability of postablative $\mathrm{T}_{\text {reg }}$ cells found that after CA, there was an overall decreased frequency of peripheral $T_{\text {reg }}$ cells and a reduction in the FoxP3 $^{+} / \mathrm{CD}^{+}$T cell ratio. ${ }^{83}$ Sabel et al used a murine model of breast cancer to demonstrate significant increases in IFN- $\gamma$ and IL-12 as well as in tumor-specific T cell responses in tumor draining lymph nodes after $C A .{ }^{84}$ Several other authors have also shown that CA confers significant resistance to rechallenge with tumoral antigens. ${ }^{11,84,85}$ An abscopal effect has even been seen, with significant postablation protection from metastases in the liver and lungs in addition to inhibition of secondary tumor growth. ${ }^{86-88}$

The immune response after CA has been shown to be more substantial than after other forms of ablation. Compared with RFA or MWA, circulating levels of IL-1, IL-6, NF-K $\beta$, and TNF- $\alpha$ are all significantly more elevated after $C^{8}{ }^{89,90}$ Loading of in vivo DCs with tumoral antigens is also vastly more efficient after CA than after RFA. ${ }^{43}$ One potential explanation for the enhanced immune response after $C A$ could be the mechanism of cell injury that it causes: hyperthermic ablative modalities like RFA and MWA destroy cellular antigens, whereas the osmotic shifts that occur with CA do not. Unlike hyperthermic techniques, the immunostimulation after CA can be so significant as to cause systemic inflammatory syndromes ${ }^{91-94}$

\section{Focused Ultrasound Ablation}

High-intensity focused ultrasound (HIFU) differs from other forms of thermal ablative therapies in that it is truly noninvasive. Traditionally, HIFU damages cells thermally by using the acoustic energy of several highly concentrated ultrasound beams to produce internal temperatures over 
Table 3 A concise description of the significant immunological effects induced by cryoablation

\begin{tabular}{|c|c|c|c|}
\hline \multicolumn{4}{|c|}{ Cryoablation } \\
\hline \multirow[t]{25}{*}{ Humans } & RCC & $\begin{array}{l}\uparrow C D 4^{+} \text {transcriptional } \\
\text { levels }\end{array}$ & 78 \\
\hline & & $\begin{array}{l}\uparrow \mathrm{CD}^{+} \text {transcriptional } \\
\text { levels }\end{array}$ & \\
\hline & & $\begin{array}{l}\uparrow C D 11 c \text { transcriptional } \\
\text { levels }\end{array}$ & \\
\hline & & $\begin{array}{l}\uparrow \text { Granzyme A transcrip- } \\
\text { tional levels }\end{array}$ & \\
\hline & & $\uparrow \mathrm{CD}^{+} / \mathrm{FoxP}^{+}$ratio & \\
\hline & & $\uparrow I L-10$ & 90 \\
\hline & & $\uparrow$ IL-6 & \\
\hline & $\mathrm{HCC}$ & $\downarrow$ FoxP3 $^{+} \mathrm{T}$ cells & 83 \\
\hline & & $\uparrow \mathrm{CD}^{+} / \mathrm{FoxP}^{+}$ratio & \\
\hline & & $\uparrow I L-10$ & 90 \\
\hline & & $\uparrow I L-6$ & \\
\hline & $\begin{array}{l}\text { Metastatic liver } \\
\text { cancer }\end{array}$ & $\uparrow \mathrm{TNF}-\alpha$ & 82 \\
\hline & & $\downarrow$ IIL-10 & \\
\hline & & $\uparrow I F N-\gamma / I L-4$ ratio & \\
\hline & Lung cancer & $\uparrow I L-10$ & 90 \\
\hline & & $\uparrow I L-6$ & \\
\hline & $\begin{array}{l}\text { Cholangiocarci- } \\
\text { noma }\end{array}$ & †TNF- $\alpha$ & 82 \\
\hline & & $\downarrow$ IIL-10 & \\
\hline & & $\uparrow I F N-\gamma / I L-4$ ratio & \\
\hline & Melanoma & $\uparrow$ Total T cells & 79 \\
\hline & & $\uparrow \mathrm{CD} 4^{+} \mathrm{T}$ cells & \\
\hline & & $\uparrow \mathrm{HLA}^{-\mathrm{DR}^{+} \text {cells }}$ & \\
\hline & & $\begin{array}{l}\uparrow \text { Helper/regulatory } T \\
\text { cell ratio }\end{array}$ & \\
\hline & & $\uparrow I L-10$ & 90 \\
\hline & & $\uparrow I L-6$ & \\
\hline \multirow[t]{11}{*}{ Animals } & $\begin{array}{l}\text { Sprague Dawley } \\
\text { rats }\end{array}$ & $\uparrow \mathrm{HSP70}$ expression & 57 \\
\hline & $\begin{array}{l}\text { BALB/c mice with } \\
\text { murine breast can- } \\
\text { cer ( } 4 \mathrm{~T} 1)\end{array}$ & $\begin{array}{l}\uparrow \text { Tumor-specific T cells } \\
\text { in TDLN } \\
\downarrow \text { Pulmonary } \\
\text { metastases }\end{array}$ & 70 \\
\hline & & $\uparrow$ Survival & \\
\hline & $\begin{array}{l}\text { BALB/c mice with } \\
\text { murine breast can- } \\
\text { cer (MT-901) }\end{array}$ & $\begin{array}{l}\text { TIL-12 } \\
\uparrow I F N-\gamma\end{array}$ & 84 \\
\hline & & $\begin{array}{l}\uparrow \text { Protection vs } \\
\text { rechallenge }\end{array}$ & \\
\hline & $\begin{array}{l}\text { BALB/c mice with } \\
\text { murine RCC (Renca) }\end{array}$ & $\begin{array}{l}\uparrow C D 4^{+} T \text { cell infiltration } \\
\uparrow C D 8^{+} T \text { cell infiltration }\end{array}$ & 80 \\
\hline & & $\uparrow$ Neutrophil infiltration & \\
\hline & & $\begin{array}{l}\text { } \text { Macrophage } \\
\text { infiltration }\end{array}$ & \\
\hline & & $\uparrow I F N-\gamma / I L-4$ ratio & \\
\hline & $\begin{array}{l}\text { Nude mice with } \\
\text { human melanoma } \\
\text { (IIB-MEL-J) }\end{array}$ & $\begin{array}{l}\uparrow \text { Neutrophil infiltration } \\
\uparrow \text { Macrophage } \\
\text { infiltration }\end{array}$ & 81 \\
\hline & $\begin{array}{l}\text { C57BL/6n mice with } \\
\text { melanoma } \\
\text { (B16OVA) }\end{array}$ & $\begin{array}{l}\text { †Protection vs rechal- } \\
\text { lenge } \\
\uparrow D C \text { loading }\end{array}$ & $\begin{array}{l}11 \\
43\end{array}$ \\
\hline
\end{tabular}

(Continued)
Table 3 (Continued)

\begin{tabular}{|c|c|c|c|}
\hline \multicolumn{4}{|c|}{ Cryoablation } \\
\hline & $\begin{array}{l}\text { BALB/c mice with } \\
\text { murine colon can- } \\
\text { cer ( } 26-B)\end{array}$ & 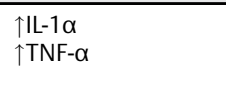 & $\begin{array}{l}86 \\
86,87\end{array}$ \\
\hline & & $\uparrow I F N-\gamma$ & \\
\hline & & $\uparrow I L-4$ & \\
\hline & & $\uparrow I L-10$ & \\
\hline & & $\begin{array}{l}\downarrow \text { Secondary tumor } \\
\text { growth }\end{array}$ & \\
\hline
\end{tabular}

Abbreviations: DC, dendritic cell; HCC, hepatocellular carcinoma; HGF, hepatocyte growth factor; HSP70, heat shock protein 70; IFN-y, interferon gamma; IL-6, interleukin 6; RCC, renal cell carcinoma; TDLN, tumor draining lymph nodes; TNF- $\alpha$, tumor necrosis factor alpha.

$60^{\circ} \mathrm{C}$. With the appropriate settings, HIFU can become mechanical high intensity focused ultrasound (M-HIFU) and cause nonthermal, mechanical damage via a process called acoustic cavitation. As the ultrasonic waves collide with the cells, the alterations in pressure cause gaseous nuclei within the cells to expand and contract, eventually leading to collapse of organelles and lysis of cellular membranes. ${ }^{10,58}$

Much like CA, HIFU has been shown to be highly immunogenic (-Table 4). Wu et al demonstrated that HIFU preserves tumor antigens and increases surface expression of HSP70, indicating that tumors treated by HIFU can stimulate an immune response. ${ }^{95}$ Multiple studies corroborating the increased expression of HSP70 have been documented, in addition to research showing that HIFU also induces HSP72 and HSP73. ${ }^{96,97}$ Several authors have shown that HIFUablated tumors significantly promote the maturation of DCs by upregulating the expression of costimulatory molecules. ${ }^{98,99}$ In particular, Xu et al used a clinical study of human breast cancer to show that HIFU significantly increased the expression of CD80 and CD86 along with HLA-DR on DCs and macrophages. Additionally, their study found that the numbers of DCs, macrophages, and B cells infiltrating the margins of ablated zones increased significantly after HIFU. ${ }^{100}$ A related study performed by Lu et al showed that HIFU also significantly increases marginal infiltration of $\mathrm{CD}^{+}, \mathrm{CD}^{+}, \mathrm{CD}^{+}, \mathrm{B}$ Cells, and NK cells. They further characterized these tumor-infiltrating lymphocytes as cytotoxic by showing a significant increase in $\mathrm{fas}^{+}$, perforin $^{+}$, and granzyme ${ }^{+}$cells postablation. ${ }^{101}$ Knowing the lymphocytes tend to infiltrate at the periphery of ablated lesions, one group of investigators set out to maximize the peripheral area created by HIFU treatment by using a "sparse scan" strategy that generated clusters of well-separated lesions. They found that this technique was significantly more effective at increasing DC infiltration and promoting their maturation than traditional dense scanning. ${ }^{102}$

In terms of cell-mediated immunity, a significant increase in $\mathrm{CD}^{+}$cells has been associated with HIFU. ${ }^{103}$ Several groups have documented cases where patients with solid malignancies had abnormal $\mathrm{CD}^{+} / \mathrm{CD}^{+}$ratios before treatment and then subsequently had $\mathrm{T}$ cell ratios normalize after 
Table 4 A concise description of the significant immunological effects induced by high-intensity focused ultrasound

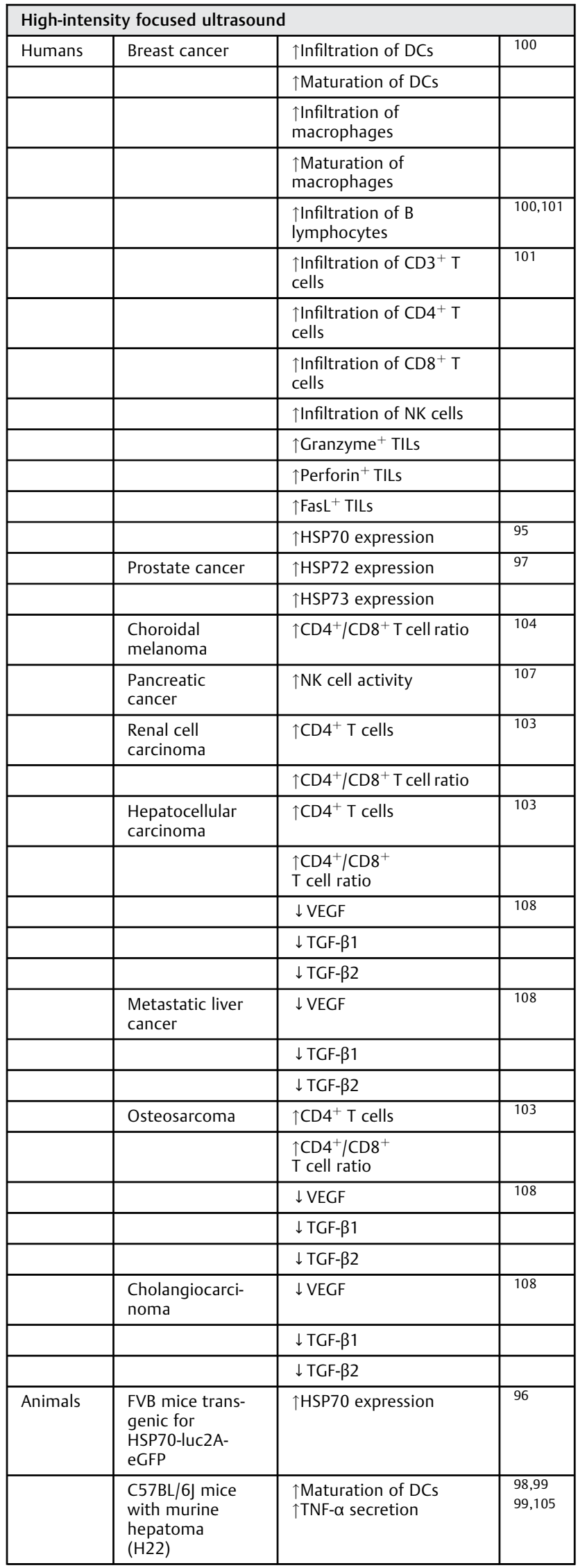

Table 4 (Continued)

\begin{tabular}{|c|c|c|}
\hline \multicolumn{3}{|c|}{ High-intensity focused ultrasound } \\
\hline & $\uparrow I F N-\gamma$ secretion & 105 \\
\hline & $\uparrow \mathrm{MHC} 1^{+} / \mathrm{CD}^{+} \mathrm{T}$ cells & \\
\hline & $\begin{array}{l}\uparrow \text { Inhibition of tumor } \\
\text { progression }\end{array}$ & \\
\hline $\begin{array}{l}\text { C57BL/6 mice } \\
\text { with murine } \\
\text { colon cancer } \\
\text { (MC38) }\end{array}$ & $\begin{array}{l}\text { } \uparrow \text { Tumor-specific IFN- } y \\
\text { secreting cells } \\
\uparrow D C \text { accumulation in } \\
\text { TDLN }\end{array}$ & 106 \\
\hline & $\begin{array}{l}\uparrow \text { Protection vs } \\
\text { rechallenge }\end{array}$ & \\
\hline & $\uparrow \mathrm{CD} 11 \mathrm{c}+$ cells & \\
\hline $\begin{array}{l}\text { C57BL/6 \& } \\
\text { BALB/C mice } \\
\text { with murine } \\
\text { glioma (GL261) }\end{array}$ & $\begin{array}{l}\downarrow \text { IL-10 expression from } \\
\text { DCs } \\
\uparrow \text { Functional recovery of } \\
\text { tolerogenic DCs }\end{array}$ & 69 \\
\hline & $\begin{array}{l}\uparrow \text { Protection vs } \\
\text { rechallenge }\end{array}$ & \\
\hline
\end{tabular}

Abbreviations: DC, dendritic cell; HGF, hepatocyte growth factor; HSP70, heat shock protein 70; IFN-y, interferon gamma; IL-6, interleukin 6; MHC-1, major histocompatibility complex 1; NK, natural killer; TDLN, -; TGF- $\beta 1$, transforming growth factor-beta 1 ; TIL, tumor-infiltrating lymphocytes; TNF- $\alpha$, tumor necrosis factor alpha; VEGF, vascular endothelial growth factor.

HIFU. ${ }^{103,104}$ Additional studies have shown that HIFU increases the number of cytotoxic $\mathrm{T}$ cells as well as the amount of IFN- $\gamma$ and TNF- $\alpha$ secretion. ${ }^{105}$ Protection against a tumoral rechallenge has also been proven to result from HIFU. Hu et al used a murine model of colon adenocarcinoma to show that thermal HIFU can protect against rechallenge in addition to increasing the accumulation of DCs into tumor draining lymph nodes as well as the number of tumorspecific cytotoxic $\mathrm{T}$ cells. ${ }^{106}$ Another clinical study that examined the use of HIFU for the treatment of late stage pancreatic carcinoma found that while HIFU did lead to a significant increase in NK activity, the increase in $\mathrm{CD}^{+}$and $\mathrm{CD}^{+}$cells was non-significant. ${ }^{107}$ One study found that in patients with various solid malignancies, HIFU decreased the circulating levels of the immunosuppressive cytokines, VEGF, TGF- $\beta 1$, and TGF- $\beta 2$. Notably they were able to further clarify that the levels of these cytokines were significantly lower after HIFU in patients with nonmetastatic disease as compared with those with metastases. ${ }^{108}$ Given the range of responses seen with differing applications of HIFU, it is possible that this variation in postablative cell mediated immunity is due to variations in technique.

Several investigators have looked specifically into the immune effects of M-HIFU. They found over several studies that M-HIFU induces a more robust release of danger signals, enhances DC and cytotoxic T cell function, and diminishes metastatic burden when compared with thermal HIFU. ${ }^{106,109,110}$ Furthermore, when used as neoadjuvant therapy for prostate cancer, M-HIFU was found to inhibit the growth of rechallenged tumors, increase the number of cytotoxic $\mathrm{T}$ cells, and prolong host survival. The authors attributed the decrease in immunosuppression to a downregulation of the tumor suppressor molecule STAT3. ${ }^{111}$ 


\section{Conclusion}

In situ modulation of malignant cells by thermal ablation may function as an in situ cancer vaccine, enhancing immunogenicity and promoting a tumor-specific immune response capable of exerting abscopal effects. The various forms of ablation have all shown this ability to some extent, though CA seems to be the most potent immunostimulant. Current and future studies investigating the incorporation of ablation into comprehensive immunotherapeutic regimens hold great potential for the treatment of solid tumors.

\section{Conflict of Interest Statement}

The authors certify that they have no affiliations with or involvement in any organization or entity with any financial interest in the subject matter or materials discussed in this manuscript. Hyun S. Kim served on Advisory boards for Boston Scientific and SIRTex.

Acknowledgments and Funding

HSK is supported by the United States Department of Defense (CA160741).

\section{References}

1 Zhu Z, Zhang J, Liu Y, Chen M, Guo P, Li K. Efficacy and toxicity of external-beam radiation therapy for localised prostate cancer: a network meta-analysis. Br J Cancer 2014;110(10):2396-2404

2 Brown LC, Mutter RW, Halyard MY. Benefits, risks, and safety of external beam radiation therapy for breast cancer. Int J Womens Health 2015;7:449-458

3 O'Brien MER, Borthwick A, Rigg A, et al. Mortality within 30 days of chemotherapy: a clinical governance benchmarking issue for oncology patients. Br J Cancer 2006;95(12):1632-1636

4 Robinson SM, Wilson CH, Burt AD, Manas DM, White SA. Chemotherapy-associated liver injury in patients with colorectal liver metastases: a systematic review and meta-analysis. Ann Surg Oncol 2012;19(13):4287-4299

5 Macadam R, Sarela A, Wilson J, MacLennan K, Guillou P. Bone marrow micrometastases predict early post-operative recurrence following surgical resection of oesophageal and gastric carcinoma. Eur J Surg Oncol 2003;29(05):450-454

6 Gu C-D, Osaki T, Oyama T, et al. Detection of micrometastatic tumor cells in pNO lymph nodes of patients with completely resected nonsmall cell lung cancer: impact on recurrence and Survival. Ann Surg 2002;235(01):133-139

7 Bilchik AJ, Hoon DS, Saha S, et al. Prognostic impact of micrometastases in colon cancer: interim results of a prospective multicenter trial. Ann Surg 2007;246(04):568-575, discussion 575-577

8 Reed J, Rosman M, Verbanac KM, Mannie A, Cheng Z, Tafra L. Prognostic implications of isolated tumor cells and micrometastases in sentinel nodes of patients with invasive breast cancer: 10-year analysis of patients enrolled in the prospective East Carolina University/Anne Arundel Medical Center Sentinel Node Multicenter Study. J Am Coll Surg 2009;208(03):333-340

9 Mehta A, Oklu R, Sheth RA. Thermal ablative therapies and immune checkpoint modulation: can locoregional approaches effect a systemic response? Gastroenterol Res Pract 2016; 2016:9251375

10 Chu KF, Dupuy DE. Thermal ablation of tumours: biological mechanisms and advances in therapy. Nat Rev Cancer 2014;14 (03):199-208

11 den Brok MH, Sutmuller RP, Nierkens S, et al. Synergy between in situ cryoablation and TLR9 stimulation results in a highly effective in vivo dendritic cell vaccine. Cancer Res 2006;66 (14):7285-7292

12 Ito F, Evans SS. Pre-resectional radiofrequency ablation as a neoadjuvant in situ tumor vaccine. J Vaccines Vaccin 2016;7 (02):310

13 Schlom J, Gulley JL. Vaccines as an integral component of cancer immunotherapy. JAMA 2018;320(21):2195-2196

14 van den Bijgaart RJE, Eikelenboom DC, Hoogenboom M, Fütterer JJ, den Brok MH, Adema GJ. Thermal and mechanical highintensity focused ultrasound: perspectives on tumor ablation, immune effects and combination strategies. Cancer Immunol Immunother 2017;66(02):247-258

15 Wen J, Duan Y, Zou Y, et al. Cryoablation induces necrosis and apoptosis in lung adenocarcinoma in mice. Technol Cancer Res Treat 2007;6(06):635-640

16 den Brok MH, Sutmuller RP, van der Voort R, et al. In situ tumor ablation creates an antigen source for the generation of antitumor immunity. Cancer Res 2004;64(11):4024-4029

17 Waitz R, Solomon SB. Can local radiofrequency ablation of tumors generate systemic immunity against metastatic disease? Radiology 2009;251(01):1-2

$18 \mathrm{Xu} \mathrm{H}$, Wang Q Lin C, et al. Synergism between cryoablation and GM-CSF: enhanced immune function of splenic dendritic cells in mice with glioma. Neuroreport 2015;26(06):346-353

19 Shi L, Chen L, Wu C, et al. PD-1 blockade boosts radiofrequency ablation-elicited adaptive immune responses against tumor. Clin Cancer Res 2016;22(05):1173-1184

20 Duffy AG, Makarova-Rusher OV, Pratt D, et al. Tremelimumab, a monoclonal antibody against CTLA-4, in combination with subtotal ablation (trans-catheter arterial chemoembolization [TACE], radiofrequency ablation [RFA] or cryoablation) in patients with hepatocellular carcinoma (HCC) and biliary tract carcinoma (BTC). J Clin Oncol 2016;34(04):270

21 Li L, Wang W, Pan H, et al. Microwave ablation combined with OK-432 induces Th1-type response and specific antitumor immunity in a murine model of breast cancer. J Transl Med 2017;15(01):23

22 Trujillo M, Alba J, Berjano E. Relationship between roll-off occurrence and spatial distribution of dehydrated tissue during RF ablation with cooled electrodes. Int J Hyperthermia: the official journal of European Society for Hyperthermic Oncology North American Hyperthermia Group. 2012;28(01):62-68

23 Pillai K, Akhter J, Chua TC, et al. Heat sink effect on tumor ablation characteristics as observed in monopolar radiofrequency, bipolar radiofrequency, and microwave, using ex vivo calf liver model. Medicine (Baltimore) 2015;94(09):e580

24 Matuszewski M, Michajłowski J, Michajłowski I, et al. Impact of radiofrequency ablation on PBMC subpopulation in patients with renal cell carcinoma. Urol Oncol 2011;29(06):724-730

25 Zerbini A, Pilli M, Laccabue D, et al. Radiofrequency thermal ablation for hepatocellular carcinoma stimulates autologous NKcell response. Gastroenterology 2010;138(05):1931-1942

26 Poli $\mathrm{A}$, Michel $\mathrm{T}$, Thérésine $\mathrm{M}$, Andrès $\mathrm{E}$, Hentges $\mathrm{F}$, Zimmer J. CD56bright natural killer (NK) cells: an important NK cell subset. Immunology 2009;126(04):458-465

27 Napoletano C, Taurino F, Biffoni M, et al. RFA strongly modulates the immune system and anti-tumor immune responses in metastatic liver patients. Int J Oncol 2008;32(02):481-490

28 Giardino A, Innamorati G, Ugel S, et al. Immunomodulation after radiofrequency ablation of locally advanced pancreatic cancer by monitoring the immune response in 10 patients. Pancreatology 2017;17(06):962-966

$29 \mathrm{Ng}$ KK, Lam CM, Poon RT, Shek TW, Ho DW, Fan ST. Safety limit of large-volume hepatic radiofrequency ablation in a rat model. Arch Surg 2006;141(03):252-258

$30 \mathrm{Ng} \mathrm{KK}$, Lam CM, Poon RT, et al. Comparison of systemic responses of radiofrequency ablation, cryotherapy, and surgical resection in a porcine liver model. Ann Surg Oncol 2004;11(07):650-657 
31 Ahmad F, Gravante G, Bhardwaj N, et al. Changes in interleukin$1 \beta$ and 6 after hepatic microwave tissue ablation compared with radiofrequency, cryotherapy and surgical resections. Am J Surg 2010;200(04):500-506

32 Evrard S, Menetrier-Caux C, Biota C, et al. Cytokines pattern after surgical radiofrequency ablation of liver colorectal metastases. Gastroenterol Clin Biol 2007;31(02):141-145

33 Schell SR, Wessels FJ, Abouhamze A, Moldawer LL, Copeland EM III. Pro- and antiinflammatory cytokine production after radiofrequency ablation of unresectable hepatic tumors. J Am Coll Surg 2002;195(06):774-781

34 Schueller G, Kettenbach J, Sedivy R, et al. Heat shock protein expression induced by percutaneous radiofrequency ablation of hepatocellular carcinoma in vivo. Int J Oncol 2004;24(03): 609-613

35 Schueller G, Kettenbach J, Sedivy R, et al. Expression of heat shock proteins in human hepatocellular carcinoma after radiofrequency ablation in an animal model. Oncol Rep 2004;12(03): 495-499

36 Haen SP, Gouttefangeas C, Schmidt D, et al. Elevated serum levels of heat shock protein 70 can be detected after radiofrequency ablation. Cell Stress Chaperones 2011;16(05):495-504

37 Yang WL, Nair DG, Makizumi R, et al. Heat shock protein 70 is induced in mouse human colon tumor xenografts after sublethal radiofrequency ablation. Ann Surg Oncol 2004;11(04):399-406

38 Todorova VK, Klimberg VS, Hennings L, Kieber-Emmons T, Pashov A. Immunomodulatory effects of radiofrequency ablation in a breast cancer model. Immunol Invest 2010;39(01):74-92

39 Liu Q, Zhai B, Yang W, et al. Abrogation of local cancer recurrence after radiofrequency ablation by dendritic cell-based hyperthermic tumor vaccine. Mol Ther 2009;17(12):2049-2057

40 Ypsilantis P, Lambropoulou M, Evagellou A, Papadopoulos N, Simopoulos C. Immune and inflammatory responses of the intestinal mucosa following extended liver radiofrequency ablation. Gastroenterol Res Pract 2017;2017:3450635

41 Schälte G, Henzler D, Waning C, Tacke J, Rossaint R, Mahnken AH. Case study of hepatic radiofrequency ablation causing a systemic inflammatory response under total intravenous anesthesia. Korean J Radiol 2010;11(06):640-647

42 Rughetti A, Rahimi H, Rossi P, et al. Modulation of blood circulating immune cells by radiofrequency tumor ablation. J Exp Clin Cancer Res CR (East Lansing Mich) 2003;22(4, Suppl):247-250

43 den Brok MH, Sutmuller RP, Nierkens S, et al. Efficient loading of dendritic cells following cryo and radiofrequency ablation in combination with immune modulation induces anti-tumour immunity. Br J Cancer 2006;95(07):896-905

44 Dromi SA, Walsh MP, Herby S, et al. Radiofrequency ablation induces antigen-presenting cell infiltration and amplification of weak tumor-induced immunity. Radiology 2009;251(01):58-66

45 Ali MY, Grimm CF, Ritter M, et al. Activation of dendritic cells by local ablation of hepatocellular carcinoma. J Hepatol 2005;43 (05):817-822

46 Fietta AM, Morosini M, Passadore I, et al. Systemic inflammatory response and downmodulation of peripheral CD25+Foxp3+ T-regulatory cells in patients undergoing radiofrequency thermal ablation for lung cancer. Hum Immunol 2009;70(07):477-486

47 Wissniowski TT, Hänsler J, Neureiter D, et al. Activation of tumorspecific T lymphocytes by radio-frequency ablation of the VX2 hepatoma in rabbits. Cancer Res 2003;63(19):6496-6500

48 Widenmeyer M, Shebzukhov Y, Haen SP, et al. Analysis of tumor antigen-specific $\mathrm{T}$ cells and antibodies in cancer patients treated with radiofrequency ablation. Int J Cancer 2011;128(11): 2653-2662

49 Hansler J, Wissniowski TT, Schuppan D, et al. Activation and dramatically increased cytolytic activity of tumor specific $\mathrm{T}$ lymphocytes after radio-frequency ablation in patients with hepatocellular carcinoma and colorectal liver metastases. World J Gastroenterol 2006;12(23):3716-3721

50 Mizukoshi E, Yamashita T, Arai K, et al. Enhancement of tumorassociated antigen-specific $\mathrm{T}$ cell responses by radiofrequency ablation of hepatocellular carcinoma. Hepatology 2013;57(04): 1448-1457

51 Hiroishi K, Eguchi J, Baba T, et al. Strong CD8(+) T-cell responses against tumor-associated antigens prolong the recurrence-free interval after tumor treatment in patients with hepatocellular carcinoma. J Gastroenterol 2010;45(04):451-458

52 Zerbini A, Pilli M, Penna A, et al. Radiofrequency thermal ablation of hepatocellular carcinoma liver nodules can activate and enhance tumor-specific T-cell responses. Cancer Res 2006;66 (02):1139-1146

53 Nijkamp MW, Borren A, Govaert KM, et al. Radiofrequency ablation of colorectal liver metastases induces an inflammatory response in distant hepatic metastases but not in local accelerated outgrowth. J Surg Oncol 2010;101(07):551-556

54 Iida N, Nakamoto Y, Baba T, et al. Antitumor effect after radiofrequency ablation of murine hepatoma is augmented by an active variant of CC Chemokine ligand 3/macrophage inflammatory protein-1alpha. Cancer Res 2010;70(16):6556-6565

55 Wright AS, Sampson LA, Warner TF, Mahvi DM, Lee FT Jr. Radiofrequency versus microwave ablation in a hepatic porcine model. Radiology 2005;236(01):132-139

56 Dong BW, Zhang J, Liang P, et al. Sequential pathological and immunologic analysis of percutaneous microwave coagulation therapy of hepatocellular carcinoma. Int J Hyperthermia: the official journal of European Society for Hyperthermic Oncology. North American Hyperthermia Group. 2003;19(02):119-133

57 Ahmad F, Gravante G, Bhardwaj N, et al. Renal effects of microwave ablation compared with radiofrequency, cryotherapy and surgical resection at different volumes of the liver treated. Liver Int 2010;30(09):1305-1314

58 Haen SP, Pereira PL, Salih HR, Rammensee H-G, Gouttefangeas C. More than just tumor destruction: immunomodulation by thermal ablation of cancer. Clin Dev Immunol 2011;2011:160250

59 Niu L-Z, Li J-L, Xu K-C. Percutaneous cryoablation for liver cancer. J Clin Transl Hepatol 2014;2(03):182-188

60 Baust JG, Gage AA. The molecular basis of cryosurgery. BJU Int 2005;95(09):1187-1191

61 Sabel MS. Cryo-immunology: a review of the literature and proposed mechanisms for stimulatory versus suppressive immune responses. Cryobiology 2009;58(01):1-11

62 Matzinger P. Tolerance, danger, and the extended family. Annu Rev Immunol 1994;12:991-1045

63 Basu S, Binder RJ, Suto R, Anderson KM, Srivastava PK. Necrotic but not apoptotic cell death releases heat shock proteins, which deliver a partial maturation signal to dendritic cells and activate the NF-kappa B pathway. Int Immunol 2000;12(11): 1539-1546

64 Bottero V, Withoff S, Verma IM. NF-kappaB and the regulation of hematopoiesis. Cell Death Differ 2006;13(05):785-797

65 Stuart LM, Lucas M, Simpson C, Lamb J, Savill J, Lacy-Hulbert A. Inhibitory effects of apoptotic cell ingestion upon endotoxindriven myeloid dendritic cell maturation. J Immunol 2002;168 (04):1627-1635

66 Garg AD, Dudek AM, Agostinis P. Cancer immunogenicity, danger signals, and DAMPs: what, when, and how? Biofactors 2013;39 (04):355-367

67 Garg AD, Agostinis P. Cell death and immunity in cancer: from danger signals to mimicry of pathogen defense responses. Immunol Rev 2017;280(01):126-148

68 Rovere P, Vallinoto C, Bondanza A, et al. Bystander apoptosis triggers dendritic cell maturation and antigen-presenting function. J Immunol 1998;161(09):4467-4471

69 He XZ, Wang QF, Han S, et al. Cryo-ablation improves anti-tumor immunity through recovering tumor educated dendritic cells in 
tumor-draining lymph nodes. Drug Des Devel Ther 2015; 9:1449-1458

70 Sabel MS, Su G, Griffith KA, Chang AE. Rate of freeze alters the immunologic response after cryoablation of breast cancer. Ann Surg Oncol 2010;17(04):1187-1193

71 Yamashita T, Hayakawa K, Hosokawa M, et al. Enhanced tumor metastases in rats following cryosurgery of primary tumor. Gan 1982;73(02):222-228

72 Hayakawa K, Yamashita T, Suzuki K, et al. Comparative immunological studies in rats following cryosurgery and surgical excision of 3-methylcholanthrene-induced primary autochthonous tumors. Gan 1982;73(03):462-469

73 Shibata T, Suzuki K, Yamashita T, et al. Immunological analysis of enhanced spontaneous metastasis in WKA rats following cryosurgery. Anticancer Res 1998;18(4A, 4a):2483-2486

74 Shibata T, Yamashita T, Suzuki K, et al. Enhancement of experimental pulmonary metastasis and inhibition of subcutaneously transplanted tumor growth following cryosurgery. Anticancer Res 1998;18(6A, 6a)4443-4448

75 Wing MG, Rogers K, Jacob G, Rees RC. Characterisation of suppressor cells generated following cryosurgery of an HSV-2induced fibrosarcoma. Cancer Immunol Immunother 1988;26 (02):169-175

76 Misao A, Sakata K, Saji S, Kunieda T. Late appearance of resistance to tumor rechallenge following cryosurgery. A study in an experimental mammary tumor of the rat. Cryobiology 1981; 18(04):386-389

77 Miya K, Saji S, Morita T, et al. Immunological response of regional lymph nodes after tumor cryosurgery: experimental study in rats. Cryobiology 1986;23(04):290-295

78 Kato T, Iwasaki T, Uemura M, et al. Characterization of the cryoablation-induced immune response in kidney cancer patients. OncoImmunology 2017;6(07):e1326441

79 Weyer U, Petersen I, Ehrke C, et al. [Immunomodulation by cryosurgery in malignant melanoma]. Onkologie 1989;12(06): 291-296

80 Matin SF, Sharma P, Gill IS, et al. Immunological response to renal cryoablation in an in vivo orthotopic renal cell carcinoma murine model. J Urol 2010;183(01):333-338

81 Gazzaniga S, Bravo A, Goldszmid SR, et al. Inflammatory changes after cryosurgery-induced necrosis in human melanoma xenografted in nude mice. J Invest Dermatol 2001;116(05):664-671

82 Osada S, Imai $\mathrm{H}$, Tomita $\mathrm{H}$, et al. Serum cytokine levels in response to hepatic cryoablation. J Surg Oncol 2007;95(06): 491-498

83 Zhou L, Fu JL, Lu YY, et al. Regulatory T cells are associated with post-cryoablation prognosis in patients with hepatitis B virusrelated hepatocellular carcinoma. J Gastroenterol 2010;45(09): 968-978

84 Sabel MS, Nehs MA, Su G, Lowler KP, Ferrara JL, Chang AE. Immunologic response to cryoablation of breast cancer. Breast Cancer Res Treat 2005;90(01):97-104

85 Redondo P, del Olmo J, López-Diaz de Cerio A, et al. Imiquimod enhances the systemic immunity attained by local cryosurgery destruction of melanoma lesions. J Invest Dermatol 2007;127 (07):1673-1680

86 Joosten JJ, Muijen GN, Wobbes T, Ruers TJ. In vivo destruction of tumor tissue by cryoablation can induce inhibition of secondary tumor growth: an experimental study. Cryobiology 2001;42 (01):49-58

87 Urano M, Tanaka C, Sugiyama Y, Miya K, Saji S. Antitumor effects of residual tumor after cryoablation: the combined effect of residual tumor and a protein-bound polysaccharide on multiple liver metastases in a murine model. Cryobiology 2003;46(03): 238-245

88 Jacob G, Li AK, Hobbs KE. A comparison of cryodestruction with excision or infarction of an implanted tumor in rat liver. Cryobiology 1984;21(02):148-156
89 Jansen MC, van Hillegersberg R, Schoots IG, et al. Cryoablation induces greater inflammatory and coagulative responses than radiofrequency ablation or laser induced thermotherapy in a rat liver model. Surgery 2010;147(05):686-695

90 Erinjeri JP, Thomas CT, Samoilia A, et al. Image-guided thermal ablation of tumors increases the plasma level of interleukin- 6 and interleukin-10. J Vasc Interv Radiol 2013;24(08):1105-1112

91 Wudel LJ Jr, Allos TM, Washington MK, Sheller JR, Chapman WC. Multi-organ inflammation after hepatic cryoablation in BALB/C mice. J Surg Res 2003;112(02):131-137

92 Chapman WC, Debelak JP, Wright Pinson C, et al. Hepatic cryoablation, but not radiofrequency ablation, results in lung inflammation. Ann Surg 2000;231(05):752-761

93 Seifert JK, Morris DL. World survey on the complications of hepatic and prostate cryotherapy. World J Surg 1999;23(02): 109-113, discussion 113-114

94 Jansen MC, van Wanrooy S, van Hillegersberg R, et al. Assessment of systemic inflammatory response (SIR) in patients undergoing radiofrequency ablation or partial liver resection for liver tumors. Eur J Surg Oncol 2008;34(06):662-667

95 Wu F, Wang ZB, Cao YD, et al. Expression of tumor antigens and heat-shock protein 70 in breast cancer cells after high-intensity focused ultrasound ablation. Ann Surg Oncol 2007;14(03): 1237-1242

96 Kruse DE, Mackanos MA, O'Connell-Rodwell CE, Contag $\mathrm{CH}$, Ferrara KW. Short-duration-focused ultrasound stimulation of Hsp70 expression in vivo. Phys Med Biol 2008;53(13): 3641-3660

97 Kramer G, Steiner GE, Gröbl M, et al. Response to sublethal heat treatment of prostatic tumor cells and of prostatic tumor infiltrating T-cells. Prostate 2004;58(02):109-120

98 Zhang Y, Deng J, Feng J, Wu F. Enhancement of antitumor vaccine in ablated hepatocellular carcinoma by high-intensity focused ultrasound. World J Gastroenterol 2010;16(28):3584-3591

99 Deng J, Zhang Y, Feng J, Wu F. Dendritic cells loaded with ultrasound-ablated tumour induce in vivo specific antitumour immune responses. Ultrasound Med Biol 2010;36(03): 441-448

100 Xu ZL, Zhu XQ, Lu P, Zhou Q, Zhang J, Wu F. Activation of tumorinfiltrating antigen presenting cells by high intensity focused ultrasound ablation of human breast cancer. Ultrasound Med Biol 2009;35(01):50-57

101 Lu P, Zhu XQ, Xu ZL, Zhou Q, Zhang J, Wu F. Increased infiltration of activated tumor-infiltrating lymphocytes after high intensity focused ultrasound ablation of human breast cancer. Surgery 2009;145(03):286-293

102 Liu F, Hu Z, Qiu L, et al. Boosting high-intensity focused ultrasound-induced anti-tumor immunity using a sparse-scan strategy that can more effectively promote dendritic cell maturation. J Transl Med 2010;8:7

103 Wu F, Wang ZB, Lu P, et al. Activated anti-tumor immunity in cancer patients after high intensity focused ultrasound ablation. Ultrasound Med Biol 2004;30(09):1217-1222

104 Rosberger DF, Coleman DJ, Silverman R, Woods S, Rondeau M, Cunningham-Rundles S. Immunomodulation in choroidal melanoma: reversal of inverted $\mathrm{CD} 4 / \mathrm{CD} 8$ ratios following treatment with ultrasonic hyperthermia. Biotechnol Ther 1994; 5(1-2):59-68

105 Xia JZ, Xie FL, Ran LF, Xie XP, Fan YM, Wu F. High-intensity focused ultrasound tumor ablation activates autologous tumorspecific cytotoxic T lymphocytes. Ultrasound Med Biol 2012;38 (08):1363-1371

106 Hu Z, Yang XY, Liu Y, et al. Investigation of HIFU-induced antitumor immunity in a murine tumor model. J Transl Med 2007; $5: 34$

107 Wang X, Sun J. High-intensity focused ultrasound in patients with late-stage pancreatic carcinoma. Chin Med J (Engl) 2002; 115(09):1332-1335 
154 Interventional Oncology in Immuno-Oncology Part 1 Slovak et al.

108 Zhou Q, Zhu XQ, Zhang J, Xu ZL, Lu P, Wu F. Changes in circulating immunosuppressive cytokine levels of cancer patients after high intensity focused ultrasound treatment. Ultrasound Med Biol 2008;34(01):81-87

$109 \mathrm{Hu} \mathrm{Z}$, Yang XY, Liu Y, et al. Release of endogenous danger signals from HIFU-treated tumor cells and their stimulatory effects on APCs. Biochem Biophys Res Commun 2005;335(01): $124-131$
110 Xing Y, Lu X, Pua EC, Zhong P. The effect of high intensity focused ultrasound treatment on metastases in a murine melanoma model. Biochem Biophys Res Commun 2008;375 (04):645-650

111 Huang X, Yuan F, Liang M, et al. M-HIFU inhibits tumor growth, suppresses STAT3 activity and enhances tumor specific immunity in a transplant tumor model of prostate cancer. PLoS One 2012;7(07):e41632 